\title{
MODEL PENGELOLAAN WAKAF PADA PUSAT PENGELOLAAN DANA SOSIAL (PUSPAS) UNIVERSITAS AIRLANGGA DALAM MENINGKATKAN PRODUKTIFITAS MUSTAHIK DI JAWA TIMUR
}

\author{
WAQAF MANAGEMENT MODEL IN IMPROVING MUSTAHIK \\ PRODUCTIVITY IN EAST JAVA AT SOCIAL FUND MANAGEMENT \\ CENTER (PUSPAS) AIRLANGGA UNIVERSITY
}

\author{
Renny Oktafia \\ Fakultas Agama Islam Universitas Muhammadiyah Sidoarjo \\ Jl. Mojopahit No. 666 B Sidoarjo \\ renny.oktafia@umsida.ac.id \\ Nihlatul Qudus SN, Muhammad Yani \\ Fakultas Bisnis, Hukum dan Ilmu Sosial Universitas Muhammadiyah Sidoarjo \\ Jl. Mojopahit No. 666 B Sidoarjo \\ nihlatul2015@gmail.com,madyani.ix@gmail.com

\section{Bobur Sobirov} \\ Samarkand Institute of Economics and Service, Uzbekistan \\ 9 Amir Temur St, Samarkand 140100, Uzbekistan \\ Mrbobursobirov@gmail.com
}

Naskah diterima 24 Juli 2020, di-review 09 September 2020, disetujui 31 Desember 2020

\begin{abstract}
This research aims to determine the model of university-based waqaf management in East Java. Higher Education as a booster for civilization change, can be used as a place to manage waqaf. Therefore, waqaf can be used as a means of improvement and enhancement of the quality of education, in order to create a more advanced civilization. This, can be used as an instrument in boosting community productivity. One of the tertiary institutions in Indonesia, which has implemented waqaf management in supporting all educational activities on campus as well as helping the surrounding community is Airlangga University. The research method used is qualitative, with a grounded research approach. The location of the research is Airlangga University, which is the only university in East Java that has officially become nadzir waqaf. In managing this waqaf, Airlangga Univeristy has appointed its work unit, namely the Social Fund Management Center (PUSPAS). Thus, PUSPAS carries out its duties to manage waqaf professionally. PUSPAS Programs focussed on several activities like Waqaf Rumah Amerta and Waqaf 1000 Movement (GEBU). These programs aims to produce productivity for all students, educators, and the community around Airlangga University in particular. In addition, all PUSPAS waqaf management activities can also have an impact on increasing the productivity of mustahik in East Java, in general
\end{abstract}

Keywords: University, Waqf, Productivity

Abstrak: Penelitian ini bertujuan untuk mengetahui model pengelolaan waqaf berbasis Perguruan Tinggi di Jawa Timur. Perguruan tinggi merupakan salah satu lembaga yang dapat dijadikan tempat dalam mengelola waqaf. Hal ini, berkaitan dengan fungsi kampus sebagai pendorong perubahan peradaban. Oleh karena itu, melalui waqaf maka dapat digunakan sebagai sarana perbaikan dan peningkatan mutu pendidikan, supaya tercipta peradaban yang lebih maju. Hal ini, dapat digunakan sebagai instrumen dalam mendorong produktivitas masyarakat. Salah satu perguruan tinggi di 
Indonesia, yang telah melaksanakan pengelolaan waqaf dalam menunjang seluruh kegiatan pendidikan di dalam kampus maupun membantu masyarakat sekitarnya adalah Universitas Airlangga. Metode penelitian yang digunakan adalah kualitatif, dengan pendekatan grounded research. Lokasi penelitian yang diambil adalah Universitas Airlangga, yang merupakan satu-satunya perguruan tinggi di Jawa Timur yang telah resmi menjadi nadzir waqaf. Dalam mengelola waqaf ini, Universitas Airlangga menunjuk unit kerjanya yaitu Pusat Pengelolaan Dana Sosial (PUSPAS). Dengan demikian, PUSPAS kemudian menjalankan tugasnya untuk mengelola waqaf secara profesional. Program yang menjadi fokus kegiatan PUSPAS adalah Waqaf Rumah Amerta dan Gerakan Waqaf 1000 (GEBU). Semua itu, bertujuan supaya menghasilkan produktifitas bagi seluruh mahasiswa, tenaga pendidik, maupun masyarakat disekitar Universitas Airlangga, secara khusus. Selain itu, seluruh kegiatan pengelolaan waqaf PUSPAS, dapat pula berdampak meningkatnya produktivitas mustahik di Jawa Timur, secara umum.

Kata Kunci: Perguruan Tinggi, Waqaf, Produktifitas

\section{PENDAHULUAN}

Dalam Islam terdapat instrumen, yang dapat dijadikan sebagai instrumen dalam mengelola kebijakan keuangan sebuah negara. Sejak zaman nabi Muhammad SAW, instrumen ini digunakan dalam mengembangkan ekonomi umat dan mengatasi permasalahan umat. Instrumen ini dikenal dengan zakat, infaq, shodaqoh dan waqaf (ZISWAF). Dengan ZISWAF ini, seluruh penduduk negeri pada zaman itu dalam kondisi sejahtera, sampai tidak ada satu pun yang berhak untuk disaluri ZISWAF, padahal dana ZISWAF yang telah dihimpun sangat besar, dan akhirnya dana ZISWAF tersebut disalurkan atau diekspor ke negara lain.

Salah satu instrumen tersebut diatas, yang sedang didorong dan dikembangkan di negara kita saat ini adalah Waqaf. Waqaf yang dimaksud disini adalah Waqaf uang. Di tengah problem sosial masyarakat Indonesia dan tuntutan akan kesejahteraan ekonomi akhir-akhir ini, keberadaan waqaf uang menjadi sangat strategis. Hal ini merupakan salah satu aspek ajaran Islam yang berdimensi spiritual, waqaf uang juga merupakan ajaran yang menekankan pentingnya kesejahteraan ekonomi (dimensi sosial) dan kesejahteraan umat.
Pada prakteknya, waqaf dapat disalurkan sebagai waqaf produktif, dimana waqaf produktif ini banyak mendukung program-program pemerintah dalam peningkatan sejahteraan bagi seluruh masyarakat. Waqaf sendiri dapat diberikan oleh individu maupun badan hukum, yang merupakan perbuatan hukum yang menyisihkan sebagian harta yang dimiliki, dan digunakan untuk keperluan umat sesuai dengan yang diatur dalam ajaran Islam. Dengan demikian secara esensi, wakqaf dapat diartikan menahan suatu harta benda, sehingga dapat digunakan manfaatnya, dengan ketentuan tidak boleh berkurang atau harus masih tetap zat (materi) bendanya ((Khairani, 2013)

Pembahasan terkait Waqaf telah banyak dilakukan pengkajian oleh para ulama, mulai hukum waqaf sampai pesan-pesan implisit yang dapat digali terkait waqaf yang terkandung dalam Al-Qur'an dan Al-Hadits. Pada salah satu hadist riwayat Imam muslim disebutkan bahwa "Apabila manusia meninggal dunia, terputuslah segala amalannya, kecuali dari tiga perkara: shadaqah jariyah, ilmu yang bermanfaat atau anak shaleh yang mendoakannya", berdasarkan hadits tersebut yang dimaksud dengan shadaqah yang diartikan 
oleh para ulama adalah waqaf. Waqaf merupakan suatu perbuatan memberikan hak milik atas harta yang tahan lama zatnya, yang dimiliki oleh waqif kepada nadzir, untuk dikelola serta dimanfaatkan untuk segala sesuatu hal menurut ketentuan syariat Islam, yang bertjuan untuk mendekatkan diri kepada Allah Swt (Bahjatulloh, 2015).

Pada beberapa uraian diatas, maka waqaf dapat juga untuk mendorong kemajuan pendidikan dalam rangka meningkatkan pula Indeks Pembangunan Manusia (IPM). Hal ini berdasarkan data, terkait masih adanya disparitas dalam akses pendidikan, terutama bagi masyarakat yang berada pada level pendapatan rendah. Menurut data yang dihimpun dari Badan Pusat Statistik (BPS) pada tahun 2018, menyatakan bahwa pada tingkat Angka Partisipasi Murni (APM) menunjukkan pada angka kisaran $40 \%$ masyarakat yang memiliki pendapatan terendah secara nasional, pada tingkat SD/ MI sederajat mencapai kisaran 97,60\%, pada tingkat SMP/MTs sederajat berada di kisaran 77,40\%, dan di tingkat SMA/MA sederajat sekitar $53,16 \%$. Berdasarkan data tersebut, maka dapat disimpulkan bahwa kalangan masyarakat yang berada di level pendapatan rendah, sangat rentan terhadap putus sekolah, ketika menuju tingkat pendidikan yang lebih tinggi (BPS, 2018).

Oleh karena itu wakaf pada saat ini pun, juga mulai dikelola oleh kalangan Perguruan tinggi, sebagai upaya mendukung pemerintah dalam meningkatkan patisipasi dan kualitas pendidikan, serta dalam upaya menuju World Class University. Potensi waqaf bagi pengembangan pendidikan, bersesuaian dengan tren saat ini di dunia pendidikan, khususnya di tingkat perguruan tinggi. Perguruan tinggi saat ini, dituntut untuk senantiasa berinovasi dan menjaga kualitas pendidikannya. Pada waktu bersamaan, perguruan tinggi dituntut untuk semakin mandiri dalam pendanaan serta berperan lebih aktif di masyarakat. Waqaf sebagai instrumen pengelolaan dana sosial, memiliki potensi sebagai sumber pendanaan perguruan tinggi, yang bersifat jangka panjang dan berdampak bagi masyarakat.

Salah perguruan tinggi yang telah mengembangkan waqaf di Jawa Timur adalah Universitas Airlangga. Dimana, Universitas Airlangga melalui Pusat Pengeloaan Dana Sosial (Puspas) yang dimilikinya, telah mengembangkan pengelolaan waqaf mulai tahun 2018. Saat ini, Universitas Airlangga merupakan universitas negeri pertama yang menjadi Nadzir (pengelola) waqaf uang di Indonesia yang terdaftar di Badan Waqaf Indonesia (BWI) per tanggal 27 September 2018, dengan nomer registrasi 3.3.00199. Selanjutnya, pihak Universitas Airlangga menunjuk Pusat Pengelolaan Dana Sosial (PUSPAS) sebagai unit kerja yang bertugas untuk menghimpun, mengelola, dan menyalurkan donasi sosial dari masyarakat, yang salah satunya adalah dana waqaf.

Berdasarkan uraian diatas, maka pada penelitian ini mengangkat permasalahan yaitu bagaimana model pengelolaan lembaga waqaf berbasis perguruan tinggi dalam meningkatkan produktifitas mustahiq di Jawa Timur. Dengan demikian, tujuan dari penelitian ini adalah untuk mengetahui model pengelolaan lembaga waqaf berbasis perguruan tinggi dalam meningkatkan produktifitas mustahiq di Jawa Timur. 


\section{Kerangka Konseptual}

\section{Konsep Wakaf}

Definisi wakaf, secara etimologi, berarti "menahan, mencegah, selama, tetap, paham, menghubungkan, mencabut, meninggalkan dan lain sebagainya". Menyatakan bahwa "kata wakaf merupakan bentuk mashdar (kada dasar) dari kalimat (waqafa-yaqifu-waqfan)." Kata waqaf sendiri dalam Kamus Besar Bahasa Indonesia bermakna: "Pemberian yang ikhlas dari seseorang berupa benda bergerak atau tidak bergerak bagi kepentingan umum yang dibentuk yang berkaitan dengan agama Islam." memberikan dari pengertian waqaf, yaitu (Haq, 2013):

1. Harta waqaf lepas/putus dari milik waqif, kecuali pendapat Hanafiyah, Malikiyah, dan menurut hukum positif.

2. Harta waqaf harus kekal, kecuali pendapat Malikiyah yang mengatakan bahwa boleh mewakafkan sesuatu walaupun akan habis dengan sekali pakai, seperti makanan, asalkan manfaatnya berlanjut.

3. Yang disedekahkan hanyalah manfaatnya saja. Menurut sudut pandang ekonomi, waqaf dapat dibagi menjadi dua, yaitu (Qahaf, 2007):

1. Waqaf langsung adalah waqaf yang diserahkan langsung kepada pihak-pihak yang berhak, sesuai ketentuan syariat Islam, berupa aset waqaf yang manfaatnya dapat langsung dipergunakan oleh masyarakat, seperti : sekolah, masjid, rumah sakit dan lainnya.

2. Waqaf produktif adalah waqaf dalam bentuk harta maupun benda, yang ditujukan untuk kegiatan produktif yang dapat menghasilkan, dan hasilnya dipergunakan sesuai dengan tujuan waqaf. Selain itu, waqaf produktif ini harus dikelola dengan profesional, sehingga mendapatkan keuntungan sesuai dengan yang diharapkan, dan dapat disalurkan menurut ketentuan waqaf, misal : waqaf tanah yang dikelola untuk tambak ikan, waqaf gedungyang disewakan untuk perkantoran, dan sebagainya.

\section{Pengembangan Wakaf di Indonesia}

Waqaf yang dipraktikkan di Ponpes Gontor ialah sebagai berikut (Rozalinda, 2015):

1. Waqaf Lembaga, Wakaf Lembaga ialah pendirian lembaga pondok pesantern di luar Ponpes Gontor pusat yang selanjutnya diwakafkan kepada Badan Waqaf sehingga menjadi Ponpes Gontor cabang.

2. Waqaf Tanah, Ponpes Gontor tidak hanya menerima waqaf dari lembaga ataupun pemerintah. Ponpes Gontor juga menerima waqaf tanah dari masyarakat yang ingin berwaqaf. Minat masyarakat dalam berwaqaf kepada Popes Gontor cukup baik yang ditunjukkan dengan pertumbuhan aset waqaf Gontor yang berasal dari masyarakat terlihat terus berkembang, terlebih setelah pendirian Badan Waqaf.

3. Waqaf Benda Bergerak, Waqaf benda bergerak yang diterima oleh Ponpes Gontor mencakup beberapa barang seperti mesin industri, cetak, potong hewan, konveksi, kendaraan, komputer, kendaraan kantor, barang-barang kelontong.

4. Waqaf Uang, Waqaf uang yang diterima oleh Ponpes Gontor utamanya berasal dari wali santri. Wali santri setiap tahun ajaran baru akan membayar iuran kepada

150 || Renny Oktafia, Nihlatul Qudus SN, Muhammad Yani, Bobur Sobirov 
Ponpes Gontor. Iuran tersebut oleh Ponpes Gontor dikelola sebagai waqaf. Artinya, dana tersebut tidaklah langsung dihabiskan untuk operasional ponpes melainkan dikelola sebagai aset pondok untuk mengoptimalkan unit-unit usaha ponpes.

Selain itu ada juga Waqaf yang disalurkan pemanfaatannya untuk rumah sakit. Di Indonesia, salah satu yang sudah mengembangkan ini adalah Rumah Sakit Islam (RSI) Malang. Dimana, RSI Malang pada tahun 2006, pengelola RSI mengajukan dana bantuan kepada Kementerian Agama untuk mengembangkan ruang perawatan VIP sebesar Rp. 2 miliar melalui program bantuan bagi nazhir wakaf (Kasdi, 2014).

Kemudian ada juga Waqaf yang dikelola oleh Yayasan Al-Khairat Palu, terdapat beberapa bentuk waqaf, yang terdiri dari (Lamuri, 2014):

1. Waqaf tanah, yang luasnya kurang lebih $0,66 \%$ dari jumlah total luas lokasi waqaf di Sulawesi Tengah. Waqaf tanah ini mayoritas memiliki nilai ekonomis tinggi, dan juga dimanfaatkan untuk membangun sarana pendidikan.

2. Waqaf pohon kelapa dan sawah, dimana menurut data yang dihimpun diperkirakan kurang lebih terdapat 600 pohon kelapa yang sedang dikelola, dan satu lokasi waqaf sawah yang merupakan bagian dari waqaf tanah yang telah diuraikan diatas.

3. Waqaf dana abadi, yang merupakan bentuk dari waqaf uang yang telah digalang sejak tahun 2001, yang bertujuan untuk meningkatkan mutu pendidikan.

4. Waqaf yang dikelola oleh Badan Waqaf Indonesia (BWI), yang telah dimanfaatkan untuk membangun sarana dan prasarana yang dibutuhkan untuk memenuhi kebutuhan umat, seperti antara lain: membangun rumah sakit haji, hotel dan asrama haji, dan rumah sakit Islam lainnya (Muslich, 2016)

\section{METODE PENELITIAN}

\section{Jenis dan Pendekatan Penelitian}

Penelitian ini berangkat dari fenomena yang ditemukan dilapangan kemudian dikembangkan pemahaman secara mendalam, alamiah, melibatkan konteks secara penuh, data dikumpulkan langsung dari partisipan langsung. Sedangkan desain penelitian ini bersifat fleksibel atau berubah-rubah sesuai dengan situasi dan kondisi data yang di dapat dilapangan.

Penelitian kualitatif ini secara spesifik lebih diarahkan pada penggunaan metode Grounded Theory. Tujuan umum dari penelitian GT adalah mengkonstruksi teori untuk memahami suatu penomena. Sebuah GT dikatakan baik jika: (1) secara induktif diperoleh dari data empirik; (2) dielaborasi secara teoritis; dan (3) diputuskan cukup memadai dengan domain dari sejumlah kriteria evaluasi.

Dalam penelitian ini, penelitiakan menggunakan metode GT untuk mengungkap tentang model pengelolaan waqaf berbasis perguruan tinggi di Pusat Pengelolaan Dana Sosial (Puspas) Universitas Airlangga yang bertujuan meningkatkan produktifitas mustahiq di Jawa Timur. GT yang belakangan menjadi Grounded Research (GR) merupakan salah satu nama metodologi penelitian kualitatif postpositivisme phenomenologik interpretif (Noeng Muhadjir, 2002). Para ahli ilmu sosial, khususnya para ahli sosiologi, berupaya 
menemukan teori berdasarkan data empirik yang kemudian disebut grounded theory, dan model penelitiannya disebut grounded research.

\section{Lokasi Penelitian}

Penelitian ini berfokus pada model pengelolaan waqaf berbasis perguruan tinggi dalam meningkatkan produktifitas mustahiq di Pusat Pengelolaan Dana Sosial (Puspas) Universitas Airlangga. Lokasi dipilih karena tempat tersebut merupakan lembaga pengelola waqaf yang berada dikampus, dan merupakan kampus pertama sebagai nadzir waqaf di Jawa Timur, bahkan pertama di Indonesia.

\section{Teknik Pengumpulan Data}

\section{Wawancara}

Wawancara merupakan salah satu teknik pengumpulan data yang dilakukan dengan berhadapan secara langsung dengan yang diwawancarai tetapi dapat juga diberikan daftar pertanyaan dahulu untuk dijawab pada kesempatan lain. Jenis wawancara yang digunakan peneliti dalam penelitian ini adalah wawancara mendalam (in-depth interview), yakni proses memperoleh keterangan untuk tujuan penelitian dan cara tanya jawab sambil bertatap muka antara pewawancara dengan informan atau orang yang diwawancarai, dengan atau apa tanpa menggunakan pedoman (guide) wawancara, dimana pewawancara dan informan terlibat dalam kehidupan sosial yang relatif lama (Noor, 2011).

\section{Dokumentasi}

Dokumen merupakan catatan peristiwa yang sudah berlalu. Dokumen bisa berbentuk tulisan, gambar, atau karya-karya monumental dari seseorang. Hasil penelitian dari observasi dan wawancara, akan lebih kredibel atau dapat dipercaya kalau didukung oleh sejarah pribadi kehidupan di masa kecil, di sekolah, di tempat kerja, di masyarakat dan autobiografi (Sugiyono, 2011). Pada penelitian ini dokumen yang dijadikan sebagai sumber data adalah data yang terdapat di Pusat Pengelolaan Dana Sosial (Puspar) Universitas Airlangga. Melalui data tersebut, peneliti memperoleh informasi tentang bagaimana model pengelolaan waqaf yang berbasis perguruan tinggi dalam meningkatkan produktifitas mustahiq di Jawa Timur beserta dengan dampak yang ditimbulkannya.

\section{Observasi}

Penelitian ini menggunakan observasi partisipasi pasif. Dimana alam penelitian ini peneliti datang di tempat kegiatan orang yang diamati tetapi tidak ikut terlibat dalam kegiatan tersebut. Dalam penelitian ini, observasi dilakukan saat peneliti terjun langsung ke Pusat Pengelolaan Dana Sosial (Puspar) Universitas Airlangga, dan mengamati kegiatan yang dilakukan oleh informan penelitian (Sugiyono, 2011).

\section{Teknik Analisis Data}

Dalam penelitian ini tahapan analisis data menggunakan tahapan yang dikembangkan oleh Colaizzi (Carpenter, 2003), yaitu sebagai berikut:

1. Mendeskripsikan fenomena yang diteliti, dalam hal ini model pengelolaan lembaga dan waqaf berbasis perguruan tinggi dalam meningkatkan produktifitas Pusat Pengelolaan Dana Sosial (Puspar) Universitas 
Airlangga, dan mengamati kegiatan yang dilakukan oleh informan penelitian.

2. Mengumpulkan deskripsi berdasarkan informasi dari informan tentang fenomena tersebut.

3. Membuat transkrip sesuai dengan deskripsi dari seluruh informan.

4. Menjabarkan makna yang diperoleh dari setiap pernyataan yang signifikan.

5. Mengorganisir kumpulan makna yang terbentuk ke dalam kelompok tema-tema.

6. Menuliskan deskripsi secara lengkap dan mendalam.

7. Kembali kepada informan untuk mendapatkan validasi dari deskripsi hasil analisis.

8. Melakukan validasi hasil analisis data langsung kepada informan.

\section{PEMBAHASAN DAN HASIL}

\section{Sejarah Wakaf PUSPAS}

Tepatnya pada tahun 2007, berdasarkan data kementerian riset teknologi dan pendidikan tinggi, jumlah unit perguruan tinggi yang terdaftar mencapai 4.054 unit. Angka ini didominasi oleh perguruan tinggi swasta yang mencapai 3.136 unit. Perguruan tinggi negeri hanya mencapai angkat 122 unit. Sisanya adalah perguruan tinggi agama dan perguruan tinggi di bawah kementerian atau lembaga negara dengan sistem kedinasan. Pengembangan potensi Waqaf yang belum optimal dan termanfaatkan dengan baik mampu di akomodasi oleh institusi pendidikan tinggi. Hal ini dikarenakan fasilitas sarana prasarana dan sumber daya manusia yang kompeten.

Salah satu perguruan tinggi yang telah mengelola dan mengembangkan waqaf uang adalah Universitas Airlangga. Hal ini ditindai dengan, telah terdaftarnya Universitas Airlangga sebagai nadzhir waqaf per tanggal 27 September 2018, dengan nomer registrasi 3.3.00199 yang dikeluarkan oleh Badan Waqaf Indonesia (BWI). Untuk pelaksaan secara teknis pengelolaan waqaf ini, Universitas Airlangga menunjuk Pusat Pengelolaan Dana Sosial (PUSPAS). PUSPAS merupakan unit kerja yang bertugas untuk menghimpun, mengelola, dan menyalurkan donasi sosial dari masyarakat.

Penunjukkan Universitas Airlangga sebagai nadzir waqaf uang menjadi peluang untuk mengoptimalkan potensi waqaf yang selama ini masih belum berkembang dengan baik utamanya di dunia perguruan tinggi. Hal ini adalah sebuah peluang untuk menggerakkan generasi muda dalam mengembangkan waqaf dari lingkungan kampus, Universitas Airlangga juga telah memiliki banyak keunggulan, berada di kota Surabaya yang merupakan kota terbesar kedua di Indonesia, sekaligus ibu kota provinsi Jawa timur. Selain itu Universitas Airlangga memiliki jumlah mahasiswa aktif yang mencapai puluhan ribu, serta alumni yang mencapai ratusan ribu, tersebar di seluruh Indonesia, bahkan di manca negara. Kemudian juga memiliki jajaran pengajar, yang kompeten di berbagai bidang keilmuan termasuk bidang waqaf, baik dalam level regional, nasional, maupun internasional. Selain itu, pengelola waqaf di universitas Airlangga dibawah unit kerja Pusat Pengelolaan Dana Sosial (PUSPAS), dijalankan secara profesional dengan sumber daya manusia yang kompeten dibidangnya.

PUSPAS memiliki sejarah singkat dalam perkembanganya. Pusat Pengelolaan Dana Sosial 
(PUSPAS) merupakan salah satu unit kerja khusus yang didirikan berdasarkan Surat Keputusan Rektor Universitas Airlangga No.1060/UN3/2016 tanggal 8 Agustus 2016 tentang Pembentukan Lembaga Manajemen Dana Sosial Universitas Airlangga (Airlangga Grand Center). Berdasarkan Surat Keputusan Rektor No.789/UN3/2017 tanggal 7 Juni 2018, Lembaga Manajemen Dana Sosial Universitas Airlangga (Airlangga Grand Center) berubah nama menjadi Pusat Pengelolaan Dana Sosial (PUSPAS). Maksud dan tujuan pendirian PUSPAS adalah menghimpun, mengelola, dan menyalurkan dana Zakat, Infaq, Shodaqoh dan Waqaf (ZISWAF) dari masyarakat, serta memberikan bantuan pendanaan yang ditujukan untuk kepentingan civitas akademika Universitas Airlangga dalam mewujudkan visi dan misi Universitas.

Waqaf Amerta Universitas Airlangga adalah wakaf uang yang dihimpun dari wakif masyarakat luas, dan dikelola secara produktif dengan prinsip menjaga nilai pokoknya serta memanfaatkan hasilnya, untuk diinvestasikan ke dalam sektorsektor ekonomi yang menguntungkan. Dengan ketentuan prosentase tertentu, yang digunakan untuk pengembangan pendidikan di lingkungan Universitas Airlangga. Waqaf Amerta merupakan program wakaf yang dijalankan oleh Universitas
Airlangga melalui PUSPAS, yang telah ditunjuk oleh Badan Wakaf Indonesia (BWI) sebagai nadzir waqaf uang pertama dari perguruan tinggi negeri. Amerta sendiri berasal dari bahasa Sansekerta yakni Amerta Devanagari secara etimologi berarti tidak mati atau kehidupan. Secara terminologi Amerta Airlangga, yang digunakan sebagai program oleh PUSPAS terinspirasi dari lambang Tirta Amerta yakni air suci yang dibawa oleh garuda bukti sebagaimana terdapat dalam logo Universitas Airlangga. Penggunaan terminologi Amerta Airlangga dihadapkan menjadi salah satu manifestasi dari Lambang universitas Airlangga yakni sebagai sumber ilmu abadi.

\section{Bentuk Penghimpunan dan Penyaluran Wakaf PUSPAS}

PUSPAS Universitas Airlangga telah terdaftar di Badan Amil Zakat Nasional sebagai Unit Pengumpul Zakat (UPZ) dan bersinergi dengan beberapa Lembaga Amil Zakat sebagai upaya optimalisasi pengelolaan donasi sosial sesuai dengan amanat yang diberikan. PUSPAS juga dapat menghimpun mengelola dan menghimpun dana wakaf karena Universitas Airlangga telah terdaftar sebagai Nazhir wakaf uang dari Badan Wakaf Indonesia (BWI). Bentuk Donasi yang dikelola oleh PUSPAS, nampak seperti tabel 1 dibawah ini.

Tabel 1.

Bentuk Usaha yang dikelola oleh PUSPAS

\begin{tabular}{|c|l|}
\hline No & \multicolumn{1}{|c|}{ Bentuk Donasi } \\
\hline 1 & Uang Tunai \\
\hline 2 & Warisan Uang Tunai \\
\hline 3 & Penamaan Gedung \\
\hline 4 & Saham \\
\hline 5 & Fund Manager \\
\hline 6 & Inventaris \\
\hline 7 & Buku \\
\hline 8 & Kendaraan dan Kelas \\
\hline
\end{tabular}

154 | Renny Oktafia, Nihlatul Qudus SN, Muhammad Yani, Bobur Sobirov 
Selain menghimpun donasi, PUSPAS juga mengelola dan menyalurkan donasi serta mengelola aset tidak bergerak seperti gedung dan tanah, serta intangible aset seperti ilmu pengetahuan. Pada tabel 2. berikut dibawah ini, diuraikan target penerimaan donasi dan realisasi jumlah dan hasil donasi yang diperoleh.

Tabel 2.

Target Penerimaan Donasi dan Realisasi Jumlah dan Hasil yang Diperoleh.

\begin{tabular}{|c|l|r|r|}
\hline No & \multicolumn{1}{|c|}{ Jenis Donasi } & \multicolumn{1}{c|}{ Target Penerimaan Donasi } & Realisasi jumlah dan hasil yang diperoleh \\
\hline 1 & Dana Sosial & 800.000 .000 & 1.260 .033 .912 \\
\hline 2 & Dana Abadi & 700.000 .000 & 234.875 .000 \\
\hline 3 & Wakaf & 1.000 .000 .000 .000 & 720.054 .976 \\
\hline 4 & Zakat & 50.000 .000 & 152.828 .500 \\
\hline 5 & Donasi peduli bencana & 40.000 .000 & 33.827 .430 \\
\hline $\begin{array}{c}\text { Total Keseluruhan Realisasi } \\
\text { Donasi pada tahun 2019 }\end{array}$ & Rp. 2.401.619.818 \\
\hline
\end{tabular}

PUSPAS mengelola dana yang telah diperoleh dan menyalurkan dalam bentuk, antara lain : beasiswa mahasiswa tidak mampu, student exchange, pengembangan soft skills, kegiatan riset dan pengembangan, pengabdian masyarakat, bantuan kesehatan, pembangunan infrastruktur pendidikan, dan lain-lain. Pada tahun 2019 target penyaluran PUSPAS sebesar Rp. 800.000.000,dan telah tersalurkan sebesar Rp 1.192.285.704,-, kepada penerima yang terdiri mahasiswa, tenaga pendidik, dan masyarakat umum.

\section{Model Pengelolaan Wakaf Program Unggulan Waqaf Amerta}

Adapun untuk Waqaf Amerta ini terdapat dua program yang menjadi unggulan dari nadzir universitas Airlangga, yakni: Gerakan Waqaf 1000 (GEBU) dan pengelolaan waqaf produktif berupa Rumah Waqaf Amerta. Gerakan Wakaf 1000 (GEBU)

Saat ini PUSPAS mempunyai sebuah program bernama Gerakan Waqaf 1000 disingkat GEBU. Gerakan Waqaf 1000 adalah sebuah gerakan ajakan untuk berwaqaf yang ditunjukkan khususnya kepada civitas Akademika universitas Airlangga dan masyarakat lainnya pada umumnya, baik sebagai individu, organisasi dan atau perusahaan.

Adapun harta yang dapat diwaqafkan dapat berupa uang tunai atau yang setara seperti logam mulia dan surat berharga yang menjadi milik penuh waqif orang yang berwaqaf. Waqif dapat mewaqafkan hartanya secara seterusnya atau permanen maupun dalam jangka waktu tertentu atau temporer. Adapun untuk penerima manfaat dari waqaf ini adalah mahasiswa, tenaga kependidikan, dosen, dan masyarakat di sekitar lingkungan Universitas Airlangga yang diwujudkan dalam bentuk beasiswa, bantuan penelitian, pengembangan kompetensi dan, pengadaan peralatan laboratorium, bantuan kesehatan, dan pengembangan infrastruktur pendidikan.

Cara berwaqaf bagi civitas Akademika dan masyarakat umum, yang ingin berwaqaf di Universitas Airlangga dapat mengikuti alur berwaqaf sebagai berikut. 
1. Calon waqif mendatangi kantor PUSPAS di kantor Menejemen Universitas Airlangga lantai tiga di hari kerja Senin sampai Jumat, pada pukul 08.00 sampai 16.00 WIB.

2. Calon waqif didampingi oleh perwakilan nadzir mendatangi Lembaga Keuangan Syariah Pengelola Waqaf Uang (LKSPWU).

3. Calon waqif mengisi Akta Ikrar Waqaf (AIW) dengan melampirkan fotokopi kartu identitas yang berlaku seperti KTP atau SIM.

4. Calon waqif menyetor nominal waqaf atau dapat secara transfer dan otomatis dana masuk ke rekening nadzir.

5. Calon waqif mengucapkan akad waqaf dan menandatangani AIW bersama dengan dua orang saksi dan satu orang pejabat bank sebagai pejabat pembuat AIW.

6. LKSPWU mencetak Sertifikat Waqaf Uang (SWU) atas nama waqif.

7. LKSPWU memberikan SWU dan AIW kepada Waqif.

Adapun syarat untuk seorang waqif perseorangan adalah sebagai berikut :

1. Dewasa,

2. Berakal sehat,

3. Tidak terhalang melakukan perbuatan hukum,

4. Pemilik sah harta benda waqaf.

Adapun syarat untuk saksi adalah sebagai berikut :

1. Dewasa, beragama

2. Islam,

3. Berakal sehat,

4. Tidak terhalang melakukan perbuatan hukum.
Sesuai dengan undang undang nomor 41 tahun 2004 tentang waqaf, bagi masyarakat yang ingin berwaqaf ke Universitas Airlangga namun tidak bisa datang langsung ke kantor PUSPAS bisa menyalurkan dana waqafnya melalui transfer ke nomor rekening khusus waqaf atas nama PUSPAS, yang bekerjasama dengan lima Bank Umum Syariah (BUS) antara lain : Bank Syariah mandiri (BSM), Bank BNI Syariah, Bank Jatim Syariah, Bank Muamalat, dan Bank CIMB Niaga Syariah. Apabila sudah melakukan transfer dana waqaf ke salah satu nomor rekening bank tersebut bisa melakukan konfirmasi ke nomor official PUSPAS Universitas Airlangga. Selain itu, PUSPAS Universitas Airlangga juga menerima waqaf dalam bentuk non uang seperti : tanah, bangunan, masjid, dan lain lain.

\section{Program Rumah Wakaf Amerta}

Program Rumah Waqaf Amerta sebagai wujud pengelolaan Waqaf Amerta PUSPAS sebagai unit kerja yang ditunjuk sebagai nadzir pengelola waqaf di Universitas Airlangga. Program ini bertujuan untuk memproduktifkan dana waqaf melalui model pengelolaan waqaf produktif. Program ini memberikan fasilitas berupa rumah beserta pendampingan, bagi mahasiswa penerima biasiswa bidikmisi, yang terpilih untuk dibimbing dalam membantu mencapai cita citanya di masa depan dan ikut berkontribusi dalam pengembangan pendidikan di Universitas Airlangga.

Rumah Waqaf Amerta adalah program pemberdayaan mahasiswa. Misi berkelanjutan selama empat tahun dengan target output berupa bisa hafal tiga juz, berahlak mulia, dan

156 | Renny Oktafia, Nihlatul Qudus SN, Muhammad Yani, Bobur Sobirov 
berjiwa entrepreneur. Pengelolaan program Rumah Waqaf Amerta ini dilakukan dengan mengelola rumah yang diwaqafkan kepada nadzir Universitas Airlangga yang di produktif kan selama empat tahun. Pendanaan operasional program ini, berasal dari zakat yang dikumpulkan oleh PUSPAS yang disalurkan sesuai 8 (delapan) Asnaf, dengan memperhatikan sifat dharruriyatnya, sedangkan investasi awal bangunan waqaf didanai oleh pendanaan waqaf uang yang akan di produktif kan selama empat tahun dengan expected return minimal 8\% per tahun dari dana yang di investasi kan.

Dalam pengelolaan Rumah Wakaf Amerta akan dilaksanakan serangkaian program pembinaan yang disebut dengan Pesantren Mahasiswa Amerta (PESMA). Program ini dilaksanakan berdasarkan hasil studi kelayakan yang layak. Di dalam PESMA ini terdapat dua program pendanaan, yaitu :

1. Beasiswa Amerta adalah beasiswa yang diberikan untuk mahasiswa Universitas Airlangga, khususnya mahasiswa penerima beasiswa Bidikmisi. Pesantren Mahasiswa Amerta (PESMA) didanai dari dana zakat maupun donasi sosial dari PUSPAS.

2. Non-beasiswa Amerta adalah program pembinaan mahasiswa Universitas Airlangga lainnya, yang mengikuti PESMA dengan biaya pribadi.

\section{PENUTUP}

\section{Kesimpulan}

Berdasarkan uraian diatas, maka dapat disimpulkan, bahwa waqaf yang dikelola oleh
Pusat Pengelolaan Dana Sosial (PUSPAS) Universitas Airlangga, diperuntukan untuk civitas akademika, masyarakat sekitar, dan atau program beasiswa bagi mahasiswa. Selain itu, terdapat dua program waqaf yang diperuntukan untuk mahasiswa dan masyarakat sekitar Universitas Airlangga. Kedua program tersebut, yaitu: pertama, Waqaf Rumah Amerta yang diperuntukan untuk penerima beasiswa bidikmisi dan Waqaf Amerta yang menyediakan Program Pesantren MahasiswaAamerta (PESMA); kedua, Gerakan Waqaf 1000 (GEBU).

\section{Saran}

Untuk lebih meningkatkan kapasitas PUSPAS dalam mengelola waqaf, maka terdapat beberapa saran dalam pengembangan PUSPAS sebagai nadzir waqaf, yaitu :

1. Meningkatkan sosialisasi dan literasi terhadap masyarakat terkait keberadaan PUSPAS maupun waqaf itu sendiri.

2. Meningkatkan sinergi dengan seluruh stake holder dalam memperluas jangkauan maupun manfaat yang bisa diberikan oleh PUPAS, terkait peningkatan produktivitas mustahik.

3. Meningkatkan inovasi-inovasi dalam melakukan pengelolaan waqaf, sehingga lebih banyak program yang bisa menjawab kebutuhan masyarakat. 


\section{DAFTAR KEPUSTAKAAN}

Bahjatulloh, Q. M. (2015). PENGEMBANGAN WAKAF TUNAI BERBASIS UMRAH DI PONDOK PESANTREN TA'MIRUL ISLAM SURAKARTA . Jurnal INFERENSI, Vol. 9, No. 1. BPS. (2018). Potret Pendidikan Indonesia, Statistik Pendidikan 2018. Jakarta: Badan Pusat Statistik.

Carpenter, S. \&. (2003). Qualitative Research in Nursing Advancing the Humanistic Imperative, 3nd. Philadephia: Lippincot Williams \& Wilkins A Wolters Kluwer Company.

Haq, A. F. (2013). Hukum Perwakafan di Indonesia . Sidoarjo: CV Dwiputra Pustaka Jaya.

Kasdi, A. (2014). Model Pemberdayaan Wakaf Produktif di Indonesia . Jurnal ZISWAF, Vol. 1, No. 1.

Khairani, E. (2013). Strategi Pengembangan Wakaf Produktif. Yogyakarta: Cahaya Iman.
Lamuri, A. B. (2014). Pengelolaan Wakaf Al Khairat Palu Sulawesi Tengah. Jurnal Hunafa , Vol. 11, No. 2.

Muslich, A. (2016). Peluang dan Tantangan Dalam Pengelolaan Wakaf. Jurnal Muaddib , Vol. 06, No. 02.

Noeng Muhadjir, H. (2002). Metodologi Penelitian Kualitatif.Yogyakarta: Sarasin.

Noor, J. (2011). Metodologi Penelitian : Skripsi, Tesis, Disertasi \& Karya Ilmiah . Jakarta: Prenada Media Group.

Qahaf, M. (2007). Manajemen Wakaf Produktif Jakarta : Khalifa.

Rozalinda. (2015). Manajemen Wakaf Produktif. Jakarta: Raja Grafindo Persada.

Sugiyono. (2011). Metode Penelitian Kuantitatif Kualitatif dan R\&D. Bandung: Alfabeta. 